\title{
FOCUS
}

\section{EXPLORING THE SIGNIFICANCE OF SOME CULTURAL AND RELIGIOUS FACTORS IN DOMESTIC VIOLENCE AMONG MUSLIM IMMIGRANT AUSTRALIANS}

\begin{abstract}
Daud Abdul-Fattah Batchelor*
Abstract: This is a largely qualitative research study that explores the issue of domestic violence (DV), particularly against Australian Muslim immigrant women. It uses a sectionality approach to focus on the closely linked factors of culture and religion that may engender DV. As patriarchy is a cultural risk factor for DV, a semiquantitative approach was taken by identifying the regions where the immigrants originated. Furthermore, it was found that Islamicallydiscordant patriarchal interpretations of the Quran and Sunnah employed by influential late classical scholars based in eastern Muslim lands has affected tafsir and legal rulings, especially of non-Maliki madhhabs. The 'sticking point' of physically striking women in verse $4: 34$ is potentially resolved as a provision for safeguarding wives in conflict zones. This research also supports the call for reforms by scholars in Qur'anic exegetical readings and fiqhi rulings on family law. Finally, this study recommends several policy recommendations enlightened with the understanding that Islam supports a compassionate and egalitarian view of marriage.
\end{abstract}

Keywords: Australia, culture, domestic violence, Islam, marriage, Muslim Immigrants.

\section{Introduction}

Evidence gathered from community leaders and Imams suggests increasing incidences of domestic violence (DV) among Australian Muslims. Highlighted by the Australian media, the issue of DV among Australian Muslims has been further exacerbated by the significant disconnect between Imams, the female victims, and spokespersons. ${ }^{1}$ To address this gap, this writer wishes to explore the import ant cultural and religious factors involved in the prevalence of DV. 
Between the 2006 and 2016 Censuses, the Muslim population in Australia increased 78 per cent to 604,244 , representing 2.6 per cent of the Australian population. Among Australian Muslims, 36.4 per cent were Australian-born, while 63.6 per cent were foreign-born immigrants hailing from 183 countries of origin.

\begin{tabular}{|l|l|c|}
\hline Country of Birth & Muslims & $\begin{array}{c}\text { Per cent of } \\
\text { the Muslim } \\
\text { population }\end{array}$ \\
\hline Australia & 219940 & 36.4 \\
\hline Pakistan & 54728 & 9.1 \\
\hline Afghanistan & 42705 & 7.1 \\
\hline Lebanon & 34192 & 5.6 \\
\hline Bangladesh & 33506 & 5.5 \\
\hline Iraq & 21137 & 3.5 \\
\hline Turkey & 20605 & 3.4 \\
\hline Iran & 18106 & 3.0 \\
\hline India & 15650 & 2.6 \\
\hline Indonesia & 13848 & 2.3 \\
\hline Saudi Arabia & 9841 & 1.6 \\
\hline Somalia & 7161 & 1.2 \\
\hline Malaysia & 7159 & 1.2 \\
\hline Fiji & 7023 & 1.2 \\
\hline Egypt & 6191 & 1.0 \\
\hline Syria & 5701 & 0.9 \\
\hline Bosnia and Herzegovina & 5561 & 0.9 \\
\hline Sudan & 4066 & 0.7 \\
\hline New Zealand & 3930 & 0.7 \\
\hline Singapore & 3751 & 0.6 \\
\hline & & \\
\hline
\end{tabular}

Table 1: Country of Birth of Australian Muslims: top 20 countries, $2016^{2}$ 


\section{Marriage and Domestic Violence amongst Muslims}

Islam considers the family to be the basic unit of society. The Qur'an views marriage as sacred:

And among His Signs is this that He created for you mates from among yourselves, that you may dwell in tranquillity (sakan) with them, and He has put love (mawaddah) and mercy (rahmah) between your (hearts). (al-Rum 30:21)

This verse implies that a husband and wife are to establish love, harmony, and compassion between themselves. Islam encourages marriage as a normative practice. The Prophet (peace be upon him) said, "Whomever Allah provides with a righteous wife, Allah has assisted him in half of his religion."3

Domestic violence is defined by WHO as "Any act of gender-based violence that results in, or is likely to result in, physical, sexual or mental harm or suffering to women, including threats of such acts, coercion or arbitrary deprivation of liberty." ${ }^{4}$ This study deals with partner abuse strictly within a marriage. It focuses on the most widespread form of DV, which is Intimate Partner Violence (IPV), or that of a husband against a wife. It is also important to note that DV is a predictor and major risk factor leading to divorce. ${ }^{5}$

Sociologists and other professionals propose different sociological, psychopathological, biological and feminist theories to help understand the nature and causes of DV. ${ }^{6}$ Since this research is concerned with DV related to culture and religion, it will focus on feminist theories. ${ }^{7}$ Feminist theories posit that "societal patriarchal structures of gender-based inequalities of power are the root of the problem. Therefore, the violence is an expression of male domination over females." ${ }^{\text {P }}$ Patriarchal norms are strong in Muslim societies ${ }^{9}$ and factors related to gender inequality are predictive of IPV prevalence. ${ }^{10}$ This study also takes up N. Isqandarova's challenge to Islamic counsellors "...to conduct a comprehensive assessment of these complex cultural and religious factors" $" 11$ when addressing issues of DV against Muslim women.

Several studies argue that "religious communities hold to values that focus on commitment and family orientation, which serve as a buffer to DV...while other studies identify the disempowering and sometimes punitive role of religion for abused women." ${ }^{12}$ Efforts to minimise DV align with the higher objectives of Islamic law (maqasid al-shari'ah) in helping to reduce harms to individuals and families. Isqandarova stressed that "psychological, physical, spiritual, and emotional trauma of DV has destructive impacts on the well-being of Muslim women." ${ }^{13}$ Muslim women experiencing DV often suffer from mental illness leading to serious social problems. ${ }^{14}$ 


\section{The Australian Situation}

Legislation in Australian States and Territories empower courts to make apprehended violence orders to protect victims or persons at risk of DV. ${ }^{15}$ Physical abuse between intimate partners and breaching a DV order are punishable by law.

In principle, Australian Muslims are required by the Qur'an to obey the law of the land unless there is a direct violation of a religious obligation. ${ }^{16}$ Islamic law currently operates informally in Australia within Muslim communities, supervised by Imams, who are members of the Australian National Imams' Council (ANIC). R. Afrouz and others note, "the experience of [DV victims when] help-seeking from religious leaders tended to be negative whenever discussed in reviewed papers." ${ }^{17}$ Muslim community leaders often try not to be involved in $\mathrm{DV}$, or attempt to convince women to stay in abusive relationships. ${ }^{18,19}$

The Australian Bureau of Census (ABC) in 2016 estimated that 23 per cent of women had experienced physical violence in their lives since the age of 15 . Australian women are three times more likely than men to experience violence from an intimate partner. ${ }^{20}$ Immigration is also linked with more cases of DV. ${ }^{21}$ Australian research indicates that the DV risk for culturally and linguistically diverse (CaLD) women is higher than for mainstream women. ${ }^{22}$

In brief, the purpose of the present investigation is:

- To help improve marital stability and promote well-being in Australian Muslim immigrant families. This requires helping married couples better understand their cultural context, as well as the predominant interpretations of Islamic texts regarding marriage and related factors which may cause discord; also, to clarify these factors for social workers, Imams, and conciliators.

- To help close the gap between women leaders and social workers on the one hand, and Imams on the other, regarding understanding scholarly interpretations of Islamic rulings on spousal roles.

\section{Research Approach}

The investigation involves literature research and informal interviews. In general, a qualitative approach was taken. However, a semiquantitative approach was applied when assessing cultural factors related to immigrants' countries of origin "by linking qualitative data with the larger cultural context from which it is derived" in order to "develop new perspectives on family violence." ${ }^{3}$ 
The informal interviews that were undertaken involved:

- An influential Imam of a large mosque in Brisbane.

- Dr Adis Duderija, Lecturer in Islamic and Gender Studies, Griffith University, Nathan.

- Head of a Muslim women's group in Brisbane.

- A Queensland government-employed social worker who deals with refugee families.

- A federal government-employed social worker involved with asylum seekers.

This study uses an intersectional approach. Intersectionality is a framework and methodology that examines how various social identities intersect at the micro-level of individual experience. Lockhart and Danis (2010) argue that an intersectional framework enhances one's underst anding of cultural competence. ${ }^{24}$ Ghafournia and Eastel stress the value of using an intersectionality approach to studying DV among immigrant women in Australia. ${ }^{25}$

The study will be limited to the following three intersections of factors related to DV:

1. Cultural factors of the country of origin, which affect the outlook of married couples about their marital roles and responsibilities.

2. Understanding of Islamic teachings on marital roles and responsibilities. A review of scholarly views on husband-wife relations in marriage based on interpretations of Quranic verse 4:34 and related verses will be made using an approach based on maqasid al-shari'ah (higher objectives of Islamic law) and the Qur'anic objectives of marriage.

3. Cultural factors in Australia contributing to DV amongst migrants.

\section{Cultural Aspects Affecting Marital Roles in Immigrants' Countries of Origin}

Sajda Nazlee stressed that:

...we must always consider the importance of distinguishing between cultural practice and true Islam, and not condemn Islam out of hand because of the customs of certain lands. ${ }^{26}$ 
Cultural aspects related to marriage from the immigrants' countries of origin can significantly influence the occurrence of DV. According to S. HassounehPhillips:

...it is important to begin to establish cultural bases for interpreting what has been previously perceived as generic, cult ure-blind phenomena (such as marriage and intimate partner abuse). ${ }^{27}$

In reviewing the literature, R. Nedegaard notes that among immigrant Muslims the:

...impact of cultural variations on IPV has not adequately been captured. ... [even though] the practice of cultural competence is an ethical obligation for practitioners in the field combating IPV. ${ }^{28}$

Nevertheless, Nedegaard found that:

there tended to be higher leniency and justification of abuse in Muslim cultures than in the Western norm...Beliefs were interwoven with patriarchal gender roles. ${ }^{29}$

I. Timshel and others also highlighted that cultural level risk factors for IPV include patriarchal beliefs. ${ }^{30}$

\section{Previewing Risks of Domestic Violence Related to Immigrant's Origin}

To obtain a guide to how external cultures impact on Muslim women in Australia, this study has developed a country index rating for the treatment of women which will hopefully help to illuminate an immigrant's marital situation in cases of DV. Such an index provides a general assessment of risk for marital discord based on countries of origin. Table 2 is the result of this new analysis for the top countries from which Muslims emigrated to Australia.

A semiquantitative method is applied for identifying the relative positions of countries in terms of treatment of women. Each parameter is first identified in quantitative terms according to published statistics. The selected countries are then 'banded' into five 20-centile bands ranging from 'very good', to 'very poor'. Countries are then awarded scores of 5, 4, 3, 2, 1, in order from the top band to the bottom. Each parameter has equal weighting. The result is then combined for the three fields and averaged to give a score out of five. Country ratings for treatment of women are shown in Table 2. 


\begin{tabular}{|c|c|c|c|c|c|c|}
\hline $\begin{array}{l}\text { Country of } \\
\text { Origin }\end{array}$ & \multicolumn{2}{|c|}{$\begin{array}{l}\text { Secondary } \\
\text { Education, Females, } \\
\text { Per cent }(\mathrm{Net})^{\mathrm{i}}\end{array}$} & $\begin{array}{l}\text { Female } \\
\text { Homicide, } \\
/ 100,000 \\
\text { inhabitants }^{\mathrm{ii}}\end{array}$ & \multicolumn{2}{|c|}{$\begin{array}{l}\text { Maternal Mortality } \\
\text { Rate, } \\
\text { per } 100,000 \text { live } \\
\text { births }^{\mathrm{iii}}\end{array}$} & $\begin{array}{l}\text { Overall } \\
\text { Rating } \\
\text { 5: v. good; } \\
\text { 4: good; } \\
\text { 3: average; } \\
\text { 2: poor; } \\
\text { 1: v. poor }\end{array}$ \\
\hline Singapore & 100 & 2016 & 0.1 & 10 & 2010 & 5 \\
\hline Australia & 93 & 2017 & 0.4 & 6 & 2010 & 4.7 \\
\hline Bosnia \& Her. & $\mathrm{N} / \mathrm{A}$ & N/A & 0.4 & 11 & 2008 & 4.5 \\
\hline Cyprus & 95 & 2015 & 0.5 & 7 & 2012 & 4.3 \\
\hline Saudi Arabia & 84 & 2013 & 0.3 & 12 & 2011 & 4.3 \\
\hline Turkey & 85 & 2016 & 0.5 & 16 & 2011 & 3.7 \\
\hline Iran & 85 & 2017 & 0.7 & 25 & 2010 & 3.7 \\
\hline Indonesia & 78 & 2015 & 0.1 & 126 & 2010 & 3.3 \\
\hline Egypt & 82 & 2017 & 0.4 & 33 & 2006 & 3.3 \\
\hline Lebanon & 65 & 2012 & 0.5 & 15 & 2012 & 3 \\
\hline Malaysia & 78 & 2017 & 0.6 & 40 & 2009 & 3 \\
\hline Fiji & 88 & 2012 & 1.5 & 30 & 2005 & 3 \\
\hline Syria* $^{*}$ & 45 & 2013 & 0.4 & 68 & 2010 & 2.7 \\
\hline Bangladesh & 67 & 2017 & 1.0 & 176 & 2010 & 2.3 \\
\hline Iraq $^{*}$ & 40 & 2007 & 2.5 & 50 & 2011 & 2.3 \\
\hline India & 62 & 2013 & 1.4 & 174 & 2012 & 2 \\
\hline Afghanistan ${ }^{*}$ & 36 & 2017 & 0.8 & 396 & 2010 & 1.3 \\
\hline Pakistan & 40 & 2017 & 1.8 & 178 & 2010 & 1 \\
\hline Somalia* & $\mathrm{N} / \mathrm{A}$ & N/A & 2.1 & 732 & 2012 & $1^{*}$ \\
\hline Sudan & 31 & 2011 & 1.6 & 311 & 2011 & 1 \\
\hline
\end{tabular}

Table 2: Treatment of Women in top 20 countries of origin for Australian Muslim Immigrants, 2016

Notes. i - World Bank 2015, UNESCO, School enrolments, secondary, female (per cent net). ii - UNDOC (UN Office of Drugs and Crime) Homicide statistics 2013. iii - World Bank. (*) Countries showing poorer conditions of women, perhaps due to conflicts. 


\begin{tabular}{|c|c|c|c|}
\hline Country & $\begin{array}{l}\text { DV/IPV Lifetime } \\
\text { Rate (per cent) }\end{array}$ & Year & Source \\
\hline Singapore & 6 & 2013 & $\begin{array}{l}\text { Bouhours, Cheong, } \\
\text { Bong and Anderson }^{31}\end{array}$ \\
\hline Indonesia & 18 & 2016 & SPHPN $^{32}$ \\
\hline Australia & 25 & 2016 & ABS \\
\hline Jordan & 30 & 2011 & Haddad and Others ${ }^{33}$ \\
\hline Saudi Arabia & 30 (men); 34 (women) & 2004 & Almosaed $^{34}$ \\
\hline Egypt & 36 & 2005 & $\begin{array}{l}\text { Egypt Demographic } \\
\text { and Health Survey }\end{array}$ \\
\hline Lebanon & $\begin{array}{l}30 \\
24 \text { (men); } 31 \text { (women) }\end{array}$ & $\begin{array}{l}2015 \\
2016\end{array}$ & $\begin{array}{l}\text { Hejase and Others } \\
\text { Akram }^{36}\end{array}$ \\
\hline Turkey & $\begin{array}{l}57 \\
25\end{array}$ & $\begin{array}{l}2000 \\
2007\end{array}$ & $\begin{array}{l}\text { Ilkkaracan }^{37} \\
\text { Kocacik and Others }^{38}\end{array}$ \\
\hline Malaysia & 39 & 2004 & $\begin{array}{l}\text { UNDP Fund for } \\
\text { Women }^{39}\end{array}$ \\
\hline Israel (Bedouins) & 48 & 2014 & $\begin{array}{l}\text { Cwikel and Others } \\
(2003)^{40}\end{array}$ \\
\hline Bangladesh & 62 (rural); 53 (urban) & 2005 & $\begin{array}{l}\text { Garcia-Moreno and } \\
\text { Others }^{41}\end{array}$ \\
\hline Pakistan & $\begin{array}{l}58 \text { (urban) } \\
75 \text { (PGRN Districts) }\end{array}$ & $\begin{array}{l}2011 \\
2013\end{array}$ & $\begin{array}{l}\text { Ali and Others }{ }^{42} \\
\text { Rutgers WPF }\end{array}$ \\
\hline Ethiopia & 71 & 2005 & $\begin{array}{l}\text { Garcia-Moreno and } \\
\text { Others }\end{array}$ \\
\hline
\end{tabular}

Table 3: Domestic Violence Figures against Women for Selected Countries Cited in Table 2

Note: 1) Where available, the rate depicted is for physical violence against women. 2) Australia, Singapore, India and Ethiopia are not Muslim majority countries so indicated rates may not reflect DV rates accurately for their Muslim citizens.

To test Table 2 for use in counselling Muslim married couples seeking help, published DV/IPV prevalence rates were obtained for the Muslim emigrant countries (Table 3). Countries in Table 2 showed reasonable correspondence in their relative positions with those in Table 3 suggesting that good national treatment of women yields lower DV/IPV prevalence rates. The study shows that DV prevalence is highest within South Asian and African communities. 
Non-Bedouin Arabs have relatively lower DV levels. Patriarchal societies Pakistan, Bangladesh and Bedouins - have high DV rates.

\section{Traditional Muslim Family Types}

Features of a few Muslim traditional cultures are provided below to better understand DV within families who migrated to Australia from these regions.

In the Arab World, Priscilla Offenhauer states that:

Men's prerogative to restrict female mobility...still compromises women's ability to work. Without family support or male guardianship, females in the Arab world, for example, still face obstacles acquiring official papers, travelling, borrowing money, or even getting medical treatment. ${ }^{44}$

For Asia, A.M. Hilsdon and S. Rozario comment that the diversity of Muslim women's lives means that while:

...Islam has a strong patriarchal element, the way it is practised and experienced by women does not depend on religion alone but on many other factors. ${ }^{45}$

For example, Malay women generally play important roles in their more egalitarian society. ${ }^{46}$ South Asian Muslim immigrants bring with them strong cultural and religious beliefs which play a positive role in their lives. ${ }^{47} \mathrm{~A}$. Venkataramani-Kothari outlines cultural factors relevant to subcontinent women among immigrant populations in the West:

The family is generally given a higher value than the individual. The South Asian community... maintains a model minority façade...victims are often encouraged to suppress evidence of violent acts within the home and community...The recommendation laid out for Muslim women is 'Chador and Char Diwar (the veil and four walls of the house)' ${ }^{48}$ This concept recommends that women remain covered and confined to the house. From early childhood, South Asian parents teach their girl-child that she would bring dire shame to them if her marriage were to fail and she was to prove a bad wife...Hence, a woman may see nothing wrong with suppression and dependence within marriage. The South Asian woman's identity is primarily derived from marriage 
and motherhood. ... A divorced woman and/or single mother is seen as having failed in the role of wife and mother. ${ }^{49}$

For South Asian couples facing DV in the West, "a majority of cases have issues of power-sharing and control. Men tend to demand total power and control... They expect their wives to submit not only to their control but also to the control of their mothers and other family members. Even in situations where the wife works outside the home, the husband holds on to the power of deciding how and where she should spend her money." ${ }^{0}$ Female migrants from African countries share many similar issues of abuse faced by South Asian Muslim women. ${ }^{51}$

\section{Pashtunwali Tribal Societies in Pakistan and Afghanistan}

Pashtunwali culture is an extremely patriarchal society. Many Pashtuns refer to Pashtunwali, a socio-political ideology inherited from their ancestors, as:

[Demanding] honour, hospitality, and generosity for anyone who asks for pardon or protection. [It is] an 'ideal-type code' including such principles as ... tor (female honour) and tarburwali (agnatic rivalry). ${ }^{52}$

A major institution is purdah, which emphasises the seclusion of women. Versions of the code are practised in other societies, e.g. Bedouins. ${ }^{53}$ Honour is crucial to Pashtun membership. ${ }^{54}$

Aaamir Jamal describes the following regarding women's status in a Pashtunwali society in northwest Pakistan:

After marriage, a woman's husband and in-laws may take control of her life [deciding] issues such as the number of children she will have, what her role in the community will be, and what are her limits in seeking education and employment. Guiding such decision-making is central to the chastity of women [namus]... Violation of a woman's honour brings disastrous consequences. ${ }^{55}$

Accordingly, Pashtun women are conditioned to perceive public space as unsafe and are often confined to the domestic sphere, ${ }^{56}$ as reflected in the proverb, "a women's best place is the house or the grave". ${ }^{57}$ Pashtunwali is considered to be responsible for structural gender inequality, ${ }^{58}$ engendering DV against women. ${ }^{59}$

Pashtunwali culture promotes practices that conflict with Islam: women do not normally inherit property; ${ }^{60}$ women are often treated as subservient; ${ }^{61}$ 
women can be married without their consent; ${ }^{62}$ women are confined to the home and hindered in seeking education despite Islam encouraging women to seek knowledge. Tribal Pashtuns "rarely compromise and prefer their traditions to Islam in the context of women's issues." 63

Islam stresses the role of men as protectors of women. This aspect is less relevant when living in secure environments but is paramount during times of insecurity. In such situations, due to the greater risk of women being abused, husbands are stricter on their wives, such as in Afghanistan, where conflict has raged for 40 years. ${ }^{64}$ If peace broke out, conditions could improve markedly for women. Jamal notes that:

In the [Pakistani] Pashtun plains region where it is relatively peaceful and where the state has more authority, rigid gender roles are giving way to recognition that women play a critical role in socio-economic and political life. ${ }^{65}$

Hence when in Australia, a Pakistani or Afghan male immigrant would need to adjust, especially in reducing his dominant control and strictures on his wife's mobility.

\section{Islamic Factors Related to Marriage Roles and Domestic Violence}

Leila Ahmed believes that Islamic texts and institutions need to be separated from patriarchal culture and reappraised by listening to the voice of equality and justice found within them. ${ }^{66}$ To obtain a broader perspective on this topic, Ahmed reviewed various works of literature on traditionalist and modern fiqh views, as well as feminist positions on spousal roles in marriage. The exegetical approach taken involves a holistic reading of relevant Qur'anic verses, hadith, asbab al-nuzul (revelatory context), concern for socio-historicity, and the maqasid al-shari'ah to interpret al-Nisa' 4:34 and related verses.

Great strides taken by women worldwide have demonstrated their considerable capabilities in public office and business. This contrasts to the 'inferior' nature that was frequently portrayed for women in classical Qur'anic tafsir. ${ }^{67}$ Valid non-demeaning re-interpretations of the authentic hadiths that women are a 'temptation' (fitnah), ${ }^{68}$ or a 'bent rib', ${ }^{69}$ have been provided. ${ }^{70}$ Karen Bauer writes that "today's 'ulama' have ... jettisoned all talk of women's inferiority." ${ }_{11}$ Biological and psychological differences do exist such that men on average have greater upper body strength and sex drive; while women are primary caretakers of children. ${ }^{72}$ 


\section{Qur'anic Worldview of Men and Women}

Many scholars hold that the Qur' an promotes a worldview of equality between men and women, that they are to establish harmonious marital relations together. ${ }^{73}$ The Qur' an reads:

And among His Signs is that He created for you mates from among yourselves, that you may dwell in tranquillity (sakan) with them, and He has put love (mawaddah) and mercy (rahmah) between your (hearts). (al-Rum 30:21)

Islam considers the family as the basic societal unit. The Prophet (pbuh) strongly encouraged marriage. Numerous Qur'anic verses instil the objective of an egalitarian relationship, such as:

It is He who created you from a single person, and made his mate of like nature, in order that he might dwell with her (in love) (al- 'Araf $7: 189)$

Mohammad Hashim Kamali writes on the comparable nature of men and women. ${ }^{74}$ The concept of Islam as a religion promoting compassion amongst Muslims is established by God's emphasis on his attributes, such as Ar-Rahman Ar-Raheem, (The Most Beneficent, The Most Merciful). The essential interests of the maqasid al-shari'ah, as portrayed by al-Shatibi and others, are the protection of life, religion, lineage, intellect, and property, all of which a healthy marriage protects.

Zainab Alwani states that,

...the Qur'an identifies behaviours consistent with DV under the umbrella of oppression [which] includes any type of injustice against another person ... [which is] clearly prohibited in Islam. The concept ... that 'believers, men and women, are protectors of one another' (9:71) is meant to be applied at the family level as well. ${ }^{75}$

\section{Qur'an-designated Spousal Roles in Marriage (Verses 4:34,128)}

The key Qur'anic verse which outlines spousal roles is 4:34 ("men are the protectors and maintainers of women..."). The asbab al-nuzul (circumstances of revelation) for this verse is as follows: 
Iyas b. 'Abdullah said: The Messenger of Allah (pbuh), instructed, "Do not beat Allah's slave women!" Then 'Umar [ibn al-Khattab] came to the Messenger (pbuh) and said, "The women have rebelled against their husbands." So, the prophet (pbuh) gave a concession in the matter of wife-beating. Subsequently, many women thronged to the family (or wives) of the prophet (pbuh) complaining about their husbands, upon which the prophet (pbuh) said, "Many women have thronged to the family (or wives) of Muhammad, complaining about their husbands. Those men are not the best among you." It was transmitted by Abu Dawud. ${ }^{76}$ Albani considers it authentic. ${ }^{77}$

Usama Hassan believes that the normative interpretation of the asbab al-nuzul is that Muhammad (pbuh) wished to ban wife-beating, which was widespread. However, the Prophet was caught in a difficult position with the 'rebellion' of wives and risked social upheaval in Madinah, so he compromised by giving a limited concession to the men who were wife-beating. The revelation, however, was in the context of the Prophet's continuing efforts to admonish men against wife-beating. ${ }^{78}$ This suggests that the Prophet (pbuh) knew the 'endpoint' of change in regard to women's status and its ideal position. There are many authentic hadith in which the Prophet repeatedly admonished men against striking their wives, for example:

Mu'awiyah asked the Prophet (S), "What is a wife's right over her husband?" He replied, "Feed her when you take food, clothe her when you clothe yourself, do not revile her face, and do not beat her." 79

\section{Trajectory of Qur'anic Admonition and the Prophet's Outlook}

It can be argued that the trajectory of Islamic teachings should have led to a full emancipation of women and egalitarian treatment. This agrees with MirHosseini's view that:

...the fuqaha's construction of women's rights is not free of logical contradictions ... Two competing voices can be detected [in the Qur'an and Sunnah], the one inspired by wahy [revelation] and the other constrained by the social order. While the first is an egalitarian voice, ... the second is a patriarchal voice, reflecting social, cultural, and political expediencies. ${ }^{80}$ 
Considering the perspective of the implied teleology of the Qur'an, it appears that divine design was to engender change progressively over time from society's former harsh treatment of women towards the Qur'an's core admonition of achieving egalitarianism and compassion, as reflected in the Prophet's (pbuh) conduct. ${ }^{81}$ Khalid Abou El-Fadl agrees,

The thorough and fair-minded researcher would observe that behind every single Qur'anic revelation regarding women was an effort to protect $[$ them $] .82$

This writer interprets that although God plans to improve women's conditions, He may have two reasons for revealing verse 4:34, which permitted wife-striking. First, Muslim men in circumstances where custom ruled that they were in charge of women, were not ready for accepting women's equivalent status, but the verse improved women's condition by limiting striking. ${ }^{83}$

Second, permission for striking may be necessary in conflict zones where wifely harm from striking is less than the potential harm to her if she disobeyed her husband. This follows the legal maxim that "the (shar' $i$ ) rule is to oppose the greater harm by considering the lesser one" ${ }^{84}$ Consider a recalcitrant wife who insists on leaving her home and going into the public space at a time of conflict. She could be kidnapped or killed by a marauding tribe. This latter interpretation can address the tension, previously unresolved, between the Qur' anic prescription for wife-beating and the Prophet's tradition of never beating his wives. This new theory on the relevance of striking in a restricted context is logically supported by evidence that harsher treatment of women is often greater in tribal societies (see Table 3), where the potential for intertribal conflict is high or chronic instability exists (e.g. Afghanistan). The theory cited here deserves further research to either confirm or refute it.

\section{Men as Managers of Women}

[Husbands] are the protectors and maintainers (qawwa'muna) of their [wives], because Allah has given the one more strength (fadhdhala) than the other, and because they support them from their means. Therefore, the righteous women are devoutly obedient (qaanitaatu), and guard in [the husband's] absence what Allah would have them guard. (al-Nisa' 4;34, First Part) 
The writer believes that fadhdhala (meaning 'excel over') relates to make attributes that make men generally stronger, unencumbered by nurturing small children, and free to roam and earn an income. Feminists overlook that, in dangerous conditions, women need male protection.

With respect to the qiwama role ('provider of subsistence to another'), "it is the husband's duty to financially support his wife, which entitles him, in turn, to be head of the household and permitted to discipline his wife." 85

A fair reading of the word qanitat in the above verse is that the wife should be obedient both to God (always) and to her husband (in certain matters). Kamali states that obedience in this verse is tied to the woman guarding her chastity. ${ }^{86}$ Obedience to the husband is not an open licence for the husband to direct the wife in matters unrelated to promoting family well-being. Amongst African immigrants in Australia experiencing DV, "the women reported that their husbands reminded them on many occasions that as the man of the house, they had the right to dominate family decisions." ${ }_{87}$ Decisions instead need to be made in consultation, since shura' is mandatory: amruhum shura' baynahum. (Q.42:38). ${ }^{88}$ A maqasid al-shari'ah perspective on ensuring the best outcome for the family does not require that the husband dominate and control his wife.

Salman al-Oadah cautions that,

A husband ... has the responsibility of taking care of his wife, protecting her, defending her honour, and fulfilling her needs regarding her religion and her worldly life. It does not mean ... he has the right to behave obstinately towards her, compel her, subject her to his will, suppress her individuality, and thus heinously negate her identity. ${ }^{89}$

Balancing the concept of qawama, by interpreting the term 'manager/ provider' in relation to egalitarianism in marriage, both sides can be considered as bosom companions in a harmonious two-way relationship, as described in the verse, "Your wives are a garment for you, and you are a garment for them" (al-Baqarah 2:187).

\section{Disciplinary Role of Husbands}

As to those women on whose part you fear disloyalty and ill-conduct (nushuuzahunna), admonish them [first], [next] refuse to share their beds, [and last] beat them [lightly] (idhribuuhunna); but if they return to obedience, seek not against them... (al-Nisa' 4:34, Second Part) 


\section{Wifely Nushuz}

Verse 4:34 permits men to discipline wives if they exhibit nushuz ('rise up', as in rebelling). Bauer interprets the verse as being:

...addressed to men and recipients of the punishments are in the feminine plural. Thus, it cannot be reversed to say that wives should admonish, avoid or beat their husbands.... The Qur' anic verse regarding wives' nushuz (4:34) is directed to husbands ...: whereas husbands confronting their wives' nushuz are advised to implement the 3-stage [procedure], the suggestion for wives dealing with husbands' nushuz is that it is 'best' to reach an 'amicable settlement.'...The final phrase makes it clear...disobedience is the cause of wives' punishment..$^{90}$

Kamali considers nushuz to be a disruption of marital harmony when one spouse fails to fulfil the required marital duties. ${ }^{91}$ Reasons mentioned in fiqh include a wife's sexual refusal. ${ }^{92}$ Disobedience to God would mean her failure to perform any obligatory act of Islam. Nushuz includes fahishah mubayyina (a grave sexual sin), ${ }^{93}$ as the Prophet (pbuh) said in his Farewell Sermon:

I order you to be good to the women, for they are with you as helpers over whom you have no power than that, except if they come with fahishah mubayyina (manifest evil behaviour). If they do that, then abandon their beds and beat them with a beating that is not harmful. ... Indeed, you have rights over your women, and your women have rights over you. As for your rights over your women, then they must not allow anyone whom you dislike treading on your bedding, nor to admit anyone in your home that you dislike. ${ }^{94}$

The Prophet's (pbuh) directive is powerful. These are his final instructions on implementing verse 4:34, stressing what still needed to be achieved by his Companions that they treat women as 'helpers', implying a measure of equivalence. Alwani describes the Qur'anic steps outlined to remedy nushuz as follows:

1) Advise them (those guilty of nushuz), 2) abandon them in bed (do not have sexual intercourse with them) 3) 'lightly beat them' ...;4) if a couple cannot resolve these issues on their own, each spouse is advised to bring a trusted person to represent him/her for arbitration. ${ }^{95}$ 


\section{Idribuhunna}

Ayesha Chaudhry notes the command wa-dribuhunna.... was unanimously understood by pre-colonial exegetes to mean 'to hit'." ${ }_{96}$ Bauer stresses that among medieval exegetes: "All sources that mention hitting ... also qualify it by saying "without inflicting injury'." ${ }_{97}$ Al-Razi on the other hand stated that "it is preferable [husbands] avoid physical discipline altogether." 98

Abd al-Hamid Abu Sulayman, in reviewing potential meanings of daraba, believed:

The one that fits best with the context of 4:34 is the meaning of 'withdrawing from, leaving and abandoning.'...[I]f after admonishing his wife and then sleeping in a separate bed, the husband finds she has still not rectified her behaviour, he leaves the marital home entirely. This was ... what Hadiths describe the prophet doing in Medina when his wives' conduct had so disappointed him. ${ }^{99}$

Alwani highlights that “in today's world, beating one's wife would surely lead to the very destruction of the family unit that this verse seeks to preserve." 100

In summary, reformist interpreters of 4:34 take the third disciplinary phase to be either first, a single symbolic strike ${ }^{101}$ done with a toothbrush (siwak) or that the husband departs for a period from home - these become the normative approaches in secure environments. It can also mean providing a (light) strike as instructed by the Prophet himself to a wife displaying "manifest evil behaviour" if doing so will correct that behaviour. Lastly, it can also signal the permissibility of physically restraining a recalcitrant wife from entering dangerous public space. With these three options, idribuhunna carries valid meanings for all times and circumstances.

Therefore, based on the above reasoning, any physical disciplining of a recalcitrant wife is impermissible in Australia for three reasons. Firstly, Australia is a secure country where the wife would not need to be physically restrained. Secondly, striking a spouse is against Australian laws. Finally, striking a spouse is against Australian practice ('urf), which means that such discipline would unlikely engender positive behavioural change in the wife. 


\section{Evidence of Patriarchal Imposition on Treatment of Wives}

In regard to the stat us of women, Hassouneh-Phillips is of the opinion that Islam brought:

.... a social reform movement focusing on social and economic justice. The most significant changes were the heightening of the stat us of women ... Introduction of Islam modified Arab practices ... to women's advantage, but patriarchal interpretations of Islam and the infusion of cultural elements destroyed the progressive nature of women's rights provided by Islam. ${ }^{102}$

Extreme fiqh positions were sometimes taken against the Qur'anic spirit, such that wives could be struck without qisas punishment on the husband unless bones were broken. ${ }^{103}$ Leila Ahmed believes that such Islamic doctrine developed within the misogynist society of Abbasid Iraq, which inherited customs from the Sasanian (Persian) Empire after its conquest. ${ }^{104}$ Let us present some evidence supporting this position.

\section{Prevalence of Domestic Violence Diminishes in Arab Lands Closer to Madinah}

If patriarchal cultures imposed themselves on Islam, it may be expected that Muslim practice in places near Madinah, from where Muhammad's (pbuh) exhortation to good treatment of women spread, would reflect its true teachings, while certain countries on the periphery of Muslim territories would still be influenced by their traditional pre-Islamic treatment of women.

Indeed, we find that compared to Saudi Arabia and Egypt, DV is higher in countries further from this core - in Afghanistan, Pakistan, and Bangladesh (Table 3). Arab lands were once strongly tribal and patriarchal. This condition changed, influenced by the Prophet's teachings. It is posited, however, that this influence did not permeate fully into nascent Muslim societies elsewhere due to a rapid influx of people accepting Muslim suzerainty without necessarily adhering to the Prophet's (pbuh) instruction on treating women well. Consequently, previously dominant nonIslamic patriarchal customs re-emerged in places distant from Madinah.

\section{Different rulings among Sunni Madhhabs on Verse 4:34}

Chaudhry, studied the Sunni madhhabs (school of thought) closely concerning their fiqhi approaches to implementing 4:34. She found that Malikis show the greatest kindness to women in their rulings: 
The most distinctive feature of Maliki jurisprudence was a suspicion that husbandly disciplinary privileges might slip easily into abusive behaviour. Hanafi jurists devoted their energies to protecting the disciplinary privileges of husbands." [While Maliki jurists showed constraint] Through their lengthening of the period of abandonment and insistence on following the three imperatives sequentially... Maliki jurists effectively delayed the application of hitting. ${ }^{105}$

Chaudhry's argument is based on three things. First, the Maliki and Shafi'i schools considered "clear proof for annulment of the marriage in cases of nonpayment for maintenance and clothing" while Abu Hanifa says it is not annulled. Second, "whereas the Hanafis did not hold husbands legally liable unless they killed their wives ... Malikis held husbands legally accountable for hitting their wives in a severe manner." 106 Third, "Shafi'i scholars expanded the definition of wifely nushuz to permit disciplining of wives for a greater range of behaviours. They [also]...protected husbands from legal accountability when they beat their wives excessively." 107

The proximity of the Maliki madhhab to the position of the Prophet in regard to women's protection is expected since this school tried to capt ure the authentic practice of Medinan Muslims. 'Ata' Ibn Aslam Ibn Safwan, an early mufti of Madinah, in his commentary on verse (4:34) said, "If the husband commanded his wife or forbade her to do something, but she disobeyed, he should not strike her but [just] get angry with her." ${ }^{108}$ According to “Ata's understanding, beating one's wife is makruh, prohibitively disliked. ${ }^{109}$

\section{Marked Changes Post-Tabari in Emphasis on Women's Inferiority}

Bauer identified a marked shift in mufassirun views after al-Tabari (839-923 $\mathrm{CE}$ ) to ones which consider women as inferior to men, which is evidence of a developing patriarchal influence:

Al-Tabari and exegetes who died before him do not refer to men's and women's inherent qualities to explain Q.2:228 or Q.4:34. But his contemporaries and later exegetes [cite] men's inherent superiority in body, mind and religion...Hadiths such as the one mentioning women's deficient rationality...increasingly became part of the post-Tabari works. ${ }^{110}$ 
Bauer shows that wifely 'obedience' was initially stressed as a form of piety and was limited:

Al-Tabari seems to limit wifely obedience to certain matters ... after al-Tabari, it is far more common for interpreters to assert the necessity of total wifely obedience. ${ }^{11}$

Bauer demonstrates how exegetes Zamakhshari (1075-1144 CE) and al-Razi (1149-1209 CE) when interpreting the role of wives in households, sided with customary practice over the interpretation of their legal schools, indicating "an increasing role of $u r f$ and the potential infusion of patriarchal views into exegetes' and fuqaha's mindsets." ${ }^{112}$ Bauer also highlights that: "In the $4^{\text {th }} / 10^{\text {th }}$ $6^{\text {th }} / 12^{\text {th }}$ centuries, tafsir ... was ... a Persian venture."

She believes that tafsirs were affected by the regional and legal affiliations of their authors. ${ }^{113}$ A remarkable concentration of exegetes existed in the immediate post-Tabari period around Nishapur and in Khurasan until 1130CE. These are all locations far from the Medinan centre of woman-favourable societal practice, in regions of strong patriarchal influence. ${ }^{114}$

\section{Patriarchal Influence in Restricting a Wife's Opportunity for Employment}

Kamali, in expanding the view that women can seek employment, suggests patriarchal influence hindered women's freedom:

Medieval society barred women from outside work that was unrelated to the family business, farming, weaving, embroidery, etc...Thus, a great deal of the subsequent restrictions on women's right to work is the product of medieval society's male-dominated culture. ${ }^{115}$

Based on this review, this writer recommends that a sizeable reform of women's figh is needed to remove patriarchal interpretations and restore a more egalitarian spousal relationship in marriage.

\section{Cultural Aspects in Australia and Domestic Violence Amongst Immigrants}

The impact of immigration often manifests itself in increased domestic stress and affects each spouse differently. 


\section{Issues facing Muslim male immigrants}

Cultural or situational factors that engender DV amongst Muslim male immigrants include unemployment or under-employment, adjustment to more egalitarian spousal roles, and feminist influences on the wife. Migration often accompanies a change in spousal power relationships:

...when these couples arrive in Australia; women often learn new skills to gain independence, such as driving, budgeting finances and pursuing higher education. Men who are used to working but arrive in Australia with limited English or cannot get their qualifications recognised, struggle to find employment [contributing] to a loss of power, stress, boredom and depression. This change in gender roles may lead to resentment among male family members, as they feel powerless ..., sometimes triggering them to abuse women. ${ }^{116}$

\section{Issues facing Muslim women immigrants}

O. Ogunsiji and others discussed issues facing African women immigrants who "have been found to be vulnerable because of language barriers, lack of knowledge of service availability, fear of deportation and lack of financial independence, which significantly impeded help-seeking."

Strong feminist influences in Australia could encourage a wife to challenge traditional marital roles. She could even develop an anti-male mindset, which would be destructive to her marriage:

Australian feminist Bettina Arndt, in her recent book, \#MenToo, argues that radical feminism, where men are presented as violent and sexist, is guilty of ... destroying what should be a bond ... and respect between the sexes. ... in society, media and the law there is a pervasive 'antimale bias' - a bias that in areas such as divorce, cancer research and DV prioritises women while denying men's rights. ${ }^{118}$ 


\section{Conclusion}

This article proposes a measure to resolve the difficulty of interpreting idribuhunna in the Qur'anic verse 4:34 for contemporary Muslim societies. Siel Devos opines:

British Muslims often find themselves torn between progressive and reformist approaches: they fully recognise that wife-beating is not justifiable - and illegal ... and that it should not be justified through Islam; however, they also struggle to find a way to justify the full abrogation of this verse through Islam. ${ }^{19}$

A proposed solution is that God intends the verse to stand unabrogated but only to avoid greater harm under dangerous conditions - and even in such cases, only permits restricted 'striking'.

Adis Duderija, following the lead of Kamali, proposes an approach based on a desire to reform women's and family figh. Kamali suggested:

Reform measures and adjustment of existing fiqh rules pertaining to family welfare and women should take their cue from the broader guidelines of the Qur' an and Sunna on fairness, human dignity, and justice. ${ }^{120}$

Duderija's ${ }^{121}$ modus operandi is to first undertake a comprehensive contextualisation by investigating the role of context in shaping the content of the Qur'an and its worldview, in this case reflecting the patriarchal culture of early Muslims. Second, as the Qur' an and Sunnah intended to change and mitigate negative aspects of prevailing practices, "the principle of 'moral trajectories' is deduced, which stipulates that the Qur'an and Sunna teachings were pointing [to future] ideals, which were not possible at the time of Revelation." Third, to ensure that the moral trajectories are teleological, with a clear purpose of attaining higher objectives of Islamic law. Fourth, key ethicoreligious principles to be achieved are identified, including justice, equality and sakina. Kamali, for instance, promotes a gender-equality approach based on the moral autonomy of individuals, equity (qist), and moderation (wasatiyya). ${ }^{122}$

Family law reform could be conducted by deliberately focusing on achieving the maqasid al-shari'ah, which aims to protect the family unit, as well as the identified Qur'anic ethical values related to marriage. Furthermore, takhayyur (selection of rulings from among legal schools) could be employed to achieve 
a more gender-just Muslim family law, such as by using parts of Maliki rulings regarding husbandly disciplinary responsibilities in the marriage law of other madhhabs. New ijtihad is also needed, Mir-Hosseini proposes that the link between 'illah (effective cause) and hukum (ruling) in many instances be reexamined in light of changes that have occurred with respect to women's status. ${ }^{123}$

Undoubtedly, the historical suppression of women's active involvement in certain Muslim societies has been a major cause in the decline of Islamic civilisation after its 'Golden Age.' A great opportunity exists in certain regions for emancipating women so that they can play a greater role in contributing to the well-being of their societies.

Analysis of the contextual complexity of the Qur'anic verses related to marital roles provides a clearer understanding of Islamic teachings on spousal roles and responsibilities. It should enhance the Muslim marital institution and societal well-being. It is unacceptable today that certain 'Islamic' communities ignore Islamic precepts regarding women in favour of their tribal cultures. It is time their leadership undert ake comprehensive reform and removal of traditional practices that conflict with Islam.

\section{Recommendations}

This research offers the following policy recommendations:

- Australian Imams need to engage with current scholarly positions regarding spousal roles, especially given today's egalitarian society. This will help them address and minimise DV and promote compassion in marital relations. Imams should also benefit from information regarding an immigrant's country of origin when providing counselling or guidance.

- Given the patriarchal upbringing of many immigrant men from the Indian Subcontinent, Africa and the Middle East, they should be provided with training on reformist views relating to marriage objectives, spousal roles, disciplining, and consultation. They can benefit from knowing that Islam promotes the kind and just treatment of wives, who are equal partners with complementary roles to those of their husbands. Consideration should be given to the fact that "Initiatives that have been most promising are those [which] have engaged with [the] religious beliefs and language of the target group, including perpetrators and with those who enabled violence and abuse to go unchallenged." ${ }^{124}$ 
- It would be opportune to arrange a meeting with female Muslim leaders to discuss current reformist interpretations of Islam and identify the way forward.

- Regular meetings between representatives of Imams and community leaders to chart a way forward in DV issues and support victims would be beneficial.

\section{Notes}

* Daud Abdul-Fattah Batchelor, Visiting Fellow, International Institute of Advanced Islamic Studies (IAIS) Malaysia.

1. Omar Hashmi and Mariam Tokhi, 'Muslim Divorce: Imams Shouldn't Be Judge, Jury and Relationship Counsellor for Marriages,' ABC News 24 April 2018. Available at: https://www.abc.net.au/news/2018-04-24/muslim-divorce-imamsshouldnt-be-judge-jury-marriage-counsellor/9688378 (Accessed on: 4 October 2019).

2. Riaz Hassan, Australian Muslims: A Demographic, Social and Economic Profile of Muslims in Australia 2018 (Adelaide: International Centre for Muslim and Non-Muslim Understanding, UNISA, 2018), Table 2.

3. Al-Tabarani, Al-Mu'jam al-Awsat, hadith no. 992 (Cairo: Dar al-Haramayn, 1995). Grade: Sahih (authentic) according to Suyuti in al-Jami ' al-Saghir, hadith no. 8685 (Beirut: Dar al-Kutub, n.d).

4. World Health Organization (WHO), Consultation on Violence against Women (Geneva: WHO, 1996), (FRH/WHD/96.26). The related term, 'Intimate Partner Violence (IPV)' is: "behaviour within an intimate relationship that causes physical, sexual or psychological harm, including acts of physical aggression, sexual coercion, psychological abuse and controlling behaviours"; see L. Heise and C. Garcia-Moreno, 'Violence by Intimate Partners,' in World Report On Violence and Health, ed. E. Krug, L.L. Dahlberg and J.A. Mercy et al. (Geneva: WHO, 2002), 88.

5. Sandra Smith and Kyle C Horst, 'Domestic Violence,' in Cultural Sociology of Divorce: An Encyclopedia, ed. Robert O Emery (Thousand Oaks, California: Sage, 2013), 397.

6. Nazila Isqandarova, Muslim Women, Domestic Violence and Psychotherapy: Theological and Clinical Issues (London: Routledge, 2019), 64-6.

7. Ibid., 65 .

8. Muhammad Tahir, 'Domestic Violence against Women in Pakistan and its Solution from an Islamic Perspective: A Critical and Analytical Study,' SSRN. Available at https://papers.ssrn.com/sol3/papers.cfm?abstract_id=2986723. (Accessed 2 October 2019); also Carolyn West, 'African Immigrant Women and Intimate Partner Violence: A Systematic Review,' Journal of Aggression, Maltreatment \& Trauma 25, no. 1 (2016): 9. 
9. S. Abugideiri, 'The Peaceful Families Project: Addressing Domestic Violence in Muslim Communities,' Partner Abuse 1, no. 3 (2010): 363-76.

10. Lori Heise and Andreas Kotsadam, 'Cross-National and Multilevel Correlates of Partner Violence: An Analysis of Data from Population-Based Surveys,' The Lancet Global Health 3, no. 6 (2015): 332-40.

11. Isqandarova, Muslim Women, 190.

12. Nafiseh Ghafournia, 'Muslim Women and Domestic Violence: Developing A Framework for Social Work Practice,' Journal of Religion and Spirituality in Social Work 36, No. 1-2 (2017): 146-7.

13. Isqandarova, Muslim Women, 186.

14. Ibid., 192.

15. The National Council to Reduce Violence against Women and their Children, Domestic Violence Laws in Australia (June 2009), 13.

16. al-Qur'an 4:59.

17. Ruksana Ayyub, 'Domestic Violence in the South Asian Muslim Immigrant Population in the United States,' Journal of Social Distress and the Homeless 9, no. 3 (2000); Ghafournia, 'Muslim Women and Domestic Violence.'

18. Ibid., H. Potter, 'Battered Black Women's Use of Religious Services and Spirituality for Assistance in Leaving Abusive Relationships,' Violence Against Women 13, no. 3 (2007): 262-84.

19. Rojan Afrouz, Beth R Crisp and Ann Taket, 'Seeking Help in Domestic Violence Among Muslim Women in Muslim-Majority and Non-Muslim-Majority Countries: A Literature Review,' Trauma, Violence \& Abuse (2018): 12.

20. Australian Bureau of Statistics (ABS), 2016 Personal Safety Survey (PSS) (November 8, 2017). Available at: https://www.abs.gov.au/ausstats/abs@.nsf/ mf/4906.0. (Accessed on: 3 November 2019).

21. Parliament of Australia, 'Domestic Violence in Australia,' (2014). Available at: https://www.aph.gov.au/parliamentary_business/committees/senate/finance_ and_public_administration/domestic_violence.

22. Nafiseh Ghafournia and Patricia Easteal, 'Are Immigrant Women Visible in Australian Domestic Violence Reports that Potentially Influence policy?' Laws 7, no. 32 (2018): 3.

23. Saadat Hassouneh-Phillips, 'Marriage is Half of Faith and the rest is Fear of Allah,' Violence Against Women 7, No. 8 (2001): 945.

24. L. Bowleg, 'The Problem With The Phrase Women And Minorities: Intersectionality - An Important Theoretical Framework For Public Health,' American Journal of Public Health 102, no. 7 (2012): 1267; L.L. Lockhart and F.S. Danis, Domestic Violence And Culturally Competent Practice (New York: Columbia University Press, 2010); As cited in Olubunmi Basirat OyewuwoGassikia, 'American Muslim Women and Domestic Violence Service Seeking: A Literature Review,' Affilia: Journal of Women and Social Work 31, no. 4 (2016): 453.

25. Ghafournia and Easteal, 'Are Immigrant Women Visible,' 2.

26. Sajda Nazlee, Feminism and Muslim Women (London: Ta-Ha Publishers, 1996), $24,46$.

27. Hassouneh-Phillips, 'Marriage is Half of Faith,' 927.

28. Nedegaard, 'Intimate partner Violence in Muslim Communities,' Arts Social Sci 
J S1:003, (2014): 29. Doi:10.4172/2151-6200.S1-003

29. Ibid., 28-9.

30. Isabelle Timshel, Edith Montgomery and Nina Dalgaard, 'A Systematic Review of Risk and Protective Factors Associated with Family Related Violence in Refugee Families,' Child Abuse \& Neglect 70 (2017): Abstract.

31. B. Bonhours, C. Cheong, B. Bong and S. Anderson, 'International Violence against Women Survey: Final Report on Singapore' (2013), Unpublished Report.

32. SPHPN, Indonesian National Women's Life Experience Survey: Study of Violence against Women and Girls (2016). Available at: https://indonesia.unfpa. org/en/publications/key-findings-2016-vaw-violence-against-women-surveyindonesia-0. (Accessed on 3 November 2019).

33. L.G. Haddad et al., 'Screening For Domestic Violence In Jordan: Validation Of An Arabic Version Of A Domestic Violence Against Women Questionnaire,' Int $J$ Women's Health 3 (2011), 79-86.

34. N. Almosaed, 'Violence Against Women: A Cross-Cultural Perspective,' Journal of Muslim Minority Affairs 24 (2004): 67-88.

35. H. J. Hejase et al., 'An Assessment of Violence against Women in Lebanon: An Exploratory Research,' European Journal of Business and Social Sciences 4, no. 3 (2015): 53.

36. As cited in Sophia Akram, 'It's Time To Talk About Violence Against Women In Lebanon,' Middle East Eye. Available at: https://www.middleeasteye.net/ opinion/its-time-talk-about-violence-against-women-lebanon. (Accessed on 3 November 2019).

37. P. Ilkkaracan, 'Exploring The Context of Women's Sexuality in Eastern Turkey,' Reproductive Health Matters 6, no. 12 (1998): 66-74.

38. Faruk Kocacik, Aziz Kutlar and Feray Erselcan, 'Domestic Violence Against Women: A Field Study in Turkey,' The Social Science Journal 44, no. 4 (2007): 713-4.

39. UNDP Fund for Women, 'Violence against Women in East and South-east Asia,' (2004).

40. J Cwikel, R. Lev-Wiesel, and A. Al-Krenawi, 'The Physical and Psychosocial Health of Bedouin Arab Women of the Negev Area of Israel The Impact of High Fertility and Pervasive Domestic Violence,' Violence Against Women 9 (2003): 240-57.

41. C. Garcia-Moreno et al., WHO Multi-Country Study On Women's Health and Domestic Violence Against Women: Initial Results On Prevalence, Health Outcomes and Women's Responses (Geneva: World Health Organization, 2005).

42. T. S. Ali, et al., 'Intimate Partner Violence in Urban Pakistan: Prevalence, Frequency and Risk Factors,' International Journal of Women's Health 3 (2011): 105-15.

43. WPF Rutgers, Domestic Violence Against Women: Prevalence and Men's Perception in PGRN Districts of Pakistan (Pakistan: Rutgers, 2013).

44. Priscilla Offenhauer, 'Women in Islamic societies: A Selected Review of Social Scientific Literature,' Federal Research Division, Library of Congress (2005): 62.

45. A-M. Hildson and S. Rozario, 'Introduction: Special Issue on Islam, gender and human rights,' Women's Studies International Forum 29 (2006): 332. 
46. For example, see Danielle Shapiro, 'Indonesia's Minangkabau: The World's Largest Matrilineal Society,' The Daily Beast, 13 July 2017. Available at: https://www.thedailybeast.com/indonesias-minangkabau-the-worlds-largestmatrilineal-society. (Accessed on 26 October 2019).

47. Ruksana Ayyub, 'The Many Faces of Domestic Violence in the South Asian American Muslim Community,' in Body Evidence: intimate Violence against South Asian Women in America, ed. Das Dasgupta (New Brunswick: Rutgers University Press, 2007), 24.

48. Ayyub, 'Domestic Violence in the South Asian Muslim Immigrant,' 241.

49. Anitha Venkataramani-Kothari, 'Understanding South Asian Immigrant Women's Experience of Violence,' in Body Evidence: intimate Violence against South Asian Women in America, ed. Das Dasgupta (New Brunswick: Rutgers University Press, 2007), 14-6.

50. Ayyub, 'The Many Faces of Domestic Violence,' 34.

51. See West, 'African Immigrant Women,' 1-14; also, Olayide Ogunsiji et al., 'Suffering and Smiling: West African Immigrant Women's Experience of Intimate Partner Violence,' Journal of Clinical Nursing 21 (2011): 1659-65.

52. Ahmed 1980, Grima 1998, Linholm 1982; Singer 1982); all cited by Aamir Jamal, 'Men's Perception of Women's Role and Girl's Education among Pashtun Tribes of Pakistan: A Qualitative Delphi Study,' Cultural and Pedagogical Inquiry 6, no. 2 (2014): 18-9.

53. A. Al-Krenawi and J.R. Graham, 'Somatization Among Bedouin-Arab Women: Differentiated by Marital Status,' Journal of Divorce and Remarriage 42, no. 1/2 (2004): 131-43.

54. Sarah Alaoui, 'Women's Status in Islam: The Line Between Culture and Religion,' Prospect Journal (2011): 2. Available at: https://prospectjournal. org/2011/02/22/womens-status-in-islam-the-line-between-culture-and-religion/. (Accessed on 3 November 2019).

55. Jamal, 'Men's Perception of Women's Role,' 19.

56. Muhammad Saeed, 'Pakhtun Men's Perceptions of the Conditions Promoting Domestic Violence in their Culture,' Unpublished PhD Thesis, The University of York (2012), 209.

57. Ibid., 200.

58. Ibid., 242, 260.

59. Ibid., 260.

60. Olivier Roy, Islam and Resistance in Afghanistan, $2^{\text {nd }}$ ed. (Cambridge: Cambridge University Press, 1990), 34; also Saeed, 'Pakhtun Men's Perceptions,' 254; Jamal, 'Men's Perception of Women's Role,' 27.

61. Ibid., 248, 257.

62. Ibid., 250; Alaoui, 'Women's Status in Islam,' 3.

63. Saeed, 'Pakhtun Men's Perceptions,' 239; Jamal, 'Men's Perception of Women's Role,' 27; Alaoui, 'Women's Status in Islam,' 2.

64. See Jamal, 'Men's Perception of Women's Role,' 24, 29: “due to continued wars and conflicts in the region, an extremist and violent version of Islam was introduced and flourished among Pashtuns... Some participants argued that the core reason for restraints placed on women [in pursuing education] is ... continued war and conflict...As emphasised by a community leader in the tribal 
region ... Continued war and conflict worsen the already entrenched gender inequalities of peacetime society."

65. Jamal, 'Men's Perception of Women's Role,' 29.

66. Leila Ahmed, Women and Gender in Islam: Historical Roots of a Modern Debate (New Haven: Yale University Press, 1992).

67. Karen Bauer, Gender Hierarchy in the Qur'an: Medieval Interpretations, Modern Responses (Cambridge, Cambridge University Press: 2017), 182-6.

68. The Prophet (pbuh) reportedly said, "I have not left behind me any fitnah (temptation) more harmful to men than women." Sahih al-Buhari, 5096.

69. Sahih al-Bukhari, Vol. 4, Book. 55, Hadith 548.

70. Nazlee, Feminism and Muslim Women, 66-9.

71. Bauer, Gender Hierarchy in the Qur'an, 15.

72. David P. Schmitt, 'The Truth About Sex Differences,' Psychology Today, 7 November 2017. Available at: https://www.psychologytoday.com/us/ articles/201711/the-truth-about-sex-differences (Accessed on 3 November 2019).

73. See, Nafiseh Ghafournia, 'Towards a New Interpretation of Quran 4:34,' Journal of Women of the Middle East and the Islamic World 15, no. 3 (2017): 11.

74. Mohammad Hashim Kamali, Shariah Law: Questions and Answers (London: OneWorld, 2017), 133-4.

75. Zainab Alwani, 'Domestic Violence,' in The Oxford Encyclopedia of Islam and Women, Ed. Natana J. Delong-Bas (Oxford: Oxford University Press, 2013), 225-6.

76. Abu Dawud, Sunan, ed. Albani and Mashhur Hasan Salman (Riyadh: Maktabah al-Ma'arif, 1417H), 325, Chapter on Wife-beating, Hadith 2145.

77. Khatib Tabrizi, Mishkat al-Masabih (The Niche of the lamps), $3^{\text {rd }}$ ed, ed. Muhammad Nasir al-Din al-Albani, Vol. 2 (Beirut: Al-Makhtab Al-Islami: 1405/1985), 973, Chapter: Treatment of Wives, Hadith 3261.

78. Usama Hasan, 'Have You Stopped Beating Your Wife? The plain truth about domestic violence and the 'Wife-beating' verse of the Qur' an, including a holistic study of important but rarely-quoted hadiths on the subject,' Critical Muslim, 3 January 2011. Available at: https://criticalmuslim.com/upfront/religion/makingreform-real-usama-hasan-asks-have-you-stopped-beating-your-wife. (Accessed on 16 October 2019).

79. Sunan Abi Dawud; Book 12, Hadith 98; Grade: Hasan or Sahih by Albani.

80. Mir-Hosseini, Ziba Mir-Hosseini, 'The Construction of Gender in Islamic Legal Thought: Strategies for Reform,' in Islamic Family Law and Justice for Muslim Women, ed. Nik Noraini Nik Badlishah (Kuala Lumpur: Sisters in Islam, 2003), 97.

81. See Hasan, 'Have You Stopped Beating Your Wife?' 13.

82. Khaled Abou El Fadl, The Great Theft: Wresting Islam from Extremists (New York: Harper Collins, 2005), 262.

83. This is generally stated as ghayr mubarrih ('non-extreme' striking without leaving a mark). Asma Barlas argues in "Believing Women" in Islam: Unreading Patriarchal Interpretations of the Qur'an (Austin: University of Texas Press, 2002), 6, that the Qur'an's provision on 'wife beating' is a restriction not a licence. 
84. Ibn Al-Qayyim, I'laam al-Muwaqqi 'in (Beirut: Dar al-Kutub, 1991) 2/6.

85. Mohammad Hashim Kamali, Mohamed Azam Mohamed Adil and Nur Ilham Ramli, 'Domestic Violence as a Ground for Dissolution of a Marriage,' IAIS Malaysia Policy Issue Papers, No. 7 (2019): 9.

86. Kamali, Shariah Law, 147.

87. Ogunsiji et al., 'Suffering and Smiling,' 1662.

88. Kocacik and Others, 'Domestic Violence Against Women,' 713-714 found from their survey of 695 married women in Turkey that "if there is in-house 'democracy,' woman is less likely to be assaulted by her partner."

89. Salman Al-Oadah, "Men are the protectors and maintainers of women ...," (n.d.); As cited in Nada Ibrahim and Mohamad Abdalla, 'A Critical Examination of Qur'an 4:34 and its Relevance to Intimate Partner Violence in Muslim Families,' Journal of Mental Health (December 2010): 16.

90. Bauer, Gender Hierarchy in the Qur'an, 170.

91. Kamali, Shariah Law, 147.

92. Ayesha S. Chaudhry, Domestic Violence and the Islamic Tradition: Ethics, Law and the Muslim Discourse on Gender (New York: Oxford University Press, 2013), 101.

93. Khalid M. Abou El Fadl, Conference of the Books: The Search for Beauty in Islam (Lanham, New York: Oxford University Press, 2001), 168-70.

94. Sunan at-Tirmidhi, Vol. 1, Book 7, Hadith 1163; also, Sahih Muslim and Sunan Ibn Majah.

95. Alwani, 'Domestic Violence,' 226.

96. Chaudhry, Domestic Violence, 80.

97. Bauer, Gender Hierarchy in the Qur'an, 212.

98. Chaudhry, Domestic Violence, 61.

99. Jonathan A. C. Brown, Misquoting Muhammad (London: OneWorld, 2015), 271.

100.Alwani, 'Domestic Violence,' 228.

101. The prominent companion, Ibn Abbas, suggested that if any beating takes place it be restricted to a single symbolic gentle strike; see Kamali and Others, 'Domestic Violence,' 22.

102.Hassouneh-Phillips (1999); As cited in Faizi, 214.

103. Bauer, Gender Hierarchy in the Qur'an, 219.

104.Leila Ahmed, Women and Gender, 65-6.

105. Chaudhry, Domestic Violence, 109-11.

106.Ibid., 115 .

107.Ibid., 117.

108. Abu Bakr Ibn al- 'Arabi, Ahkam al-Qur'an, Vol. 1, 420; As cited in Ibn Ashur, al-Tahrir wal-Tanwir, Vol. 5, (Tunis: al-Dar al-Tunisiyyah li al-Nashr, 1984), 44.

109. Muhammad El-Arabawy Hashem, 'Wife Beating: Modern Readings of the Qur'an (4:34),' Al-Azhar University Journal of Faculty of languages and Translation, No. 3, Part 2 (2012): 30.

110. Bauer, Gender Hierarchy in the Qur'an, 182.

111. Ibid., 194.

112. Ibid., 164.

113. Ibid., 277-8. 
114. See Alaoui, 'Women's Status in Islam.'

115. Kamali, Shariah Law, 148-9.

116. Anita Raj and Jay Silverman, 'Violence Against Immigrant Women: The Roles of Culture, Context, And Legal Immigrant Status On Intimate Partner Violence,' Violence against Women 8, no. 3 (2002): 367-98.

117. Ogunsiji et al., 'Suffering and Smiling,' 1663.

118. Kevin Donnelly, 'I Know All About Toxic Masculinity; Toxic Feminism Isn't the Answer,' Sydney Morning Herald, 17 January 2019. Available at: https:// www.smh.com.au/national/i-know-all-about-toxic-masculinity-toxic-feminismisn-t-the-answer-20190117-p50ryg.html. (Accessed on 3 November 2019).

119. Siel Devos, 'The Feminist Challenge of Qur'an Verse 4:34: An Analysis of Progressive and Reformist Approaches and Their Impact in British Muslim Communities,' Unpublished MA Thesis, SOAS, University of London (2015), 36.

120. See Adis Duderija, 'Maqasid al-Shari'a, Gender Non-patriarchal Qur'an-Sunna Hermeneutics, and the Reformation of Muslim Family Law,' in Maqasid alShari' $a$ and Contemporary Reformist Muslim Thought: An Examination, ed. A. Duderija (New York: Palgrave Macmillan, 2014), 194.

121.Ibid., 208-13.

122. Mohammad Hashim Kamali, 'Maqasid al-Shari'ah and Ijtihad as Instruments of Civilisational Renewal: A Methodological Perspective,' Islam and Civilisational Renewal Journal 2, no. 2 (2011): 245-71.

123. Mir-Hosseini, 'The Construction of Gender,' 116.

124.S. Holmes, Northern Interfaith Respectful Relationships: Project Report, (Victoria: City of Darebin, 2012) Available at: https://trove.nla.gov.au/work/167 609336?q\&versionId=182678835. (Accessed on 5 November 2019). 